\title{
Petrology and Geochemistry of Mid-Ocean Ridge Basalts from the Southern Central Indian Ridge
}

\author{
Hiroshi Sato, Kentaro Nakamura, Hidenori Kumagai, Ryoko Senda, \\ Tomoaki Morishita, Akihiro Tamura, and Shoji Arai
}

\begin{abstract}
Two hydrothermal fields, the Kairei and Edmond hydrothermal fields, are known in the southern Central Indian Ridge (CIR). The Kairei hydrothermal field at $25^{\circ} 19^{\prime} \mathrm{S}$ is associated with hydrogen-rich hydrothermal activity, whereas the Edmond hydrothermal field at $23^{\circ} 52^{\prime} \mathrm{S}$ is recognized in the typical mid-ocean ridge type hydrothermal activity. Differences of lithology and geological background between two hydrothermal fields are reflected in the different type of hydrothermal activity. We recovered more than $870 \mathrm{~kg}$ of rock samples by dredging from the southern part of the CIR adjacent to the Kairei and Edmond hydrothermal fields during the KH-10-6 cruise. Here, we present new petrological and geochemical data for MORB samples taken between the CIR-S1 and CIR-S4 segments with the aim of constraining distributions of lithology at the southern CIR, and discuss the petrogenesis and the mantle source for these basalts. The MORB melts that formed rocks within the CIR-S1, CIR-S2, and CIR-S4 segments equilibrated with mantle olivine at approximately $10 \mathrm{kbar}$, and were erupted after undergoing only minor fractionation. MORB samples from the CIR-S4 segment have slightly depleted trace element compositions, whereas MORB samples from the off-ridge part of the CIR-S1 segment are highly depleted. MORB samples from the Knorr seamount have enriched compositions involved a minor amount of hotspot-derived material, as indicated by previous isotope analyses. The presence of a depleted MORB source beneath the off-ridge section of the CIR-S1 segment indicates that the older mantle material at the boundary between the
\end{abstract}

The online version of this chapter (doi:10.1007/978-4-431-54865-2_13) contains supplementary material, which is available to authorized users.

H. Sato $(\bowtie)$

School of Business Administration, Senshu University, 2-1-1

Higashimita, Tama-ku, Kawasaki, Kanagawa 214-8580, Japan

K. Nakamura

Precambrian Ecosystem Laboratory (PEL), Japan Agency for Marine-

Earth Science and Technology (JAMSTEC), 2-15 Natsushima,

Yokosuka, Kanagawa 237-0061, Japan

Department of Systems Innovation, School of Engineering,

The University of Tokyo, 7-3-1 Hongo, Bunkyo-ku,

Tokyo 113-8656, Japan

H. Kumagai

Institute for Research on Earth Evolution, Japan Agency for MarineEarth Science and Technology, 2-15 Natsushima-cho, Yokosuka, Kanagawa 237-0061, Japan

R\&D Center for Submarine Resources, Japan Agency for MarineEarth Science and Technology, 2-15 Natsushima-cho, Yokosuka, Kanagawa 237-0061, Japan

R. Senda

Institute for Research on Earth Evolution, Japan Agency for MarineEarth Science and Technology, 2-15 Natsushima-cho, Yokosuka, Kanagawa 237-0061, Japan

Department of Solid Earth Geochemistry, Japan Agency for MarineEarth Science and Technology, 2-15 Natsushima-cho, Yokosuka, Kanagawa 237-0061, Japan

T. Morishita $\bullet$ A. Tamura $\bullet$ S. Arai

Faculty of Natural Systems, Institute of Science and Engineering, Kanazawa University, Kakuma, Kanazawa, Ishikawa 920-1192, Japan 
CIR-S1 and CIR-S2 segments was highly depleted. In turn, this suggests that the source mantle beneath the southern CIR is heterogeneous both along and across the present spreading axis, and that the composition of the mantle in this area is a function of the degree of mixing between depleted and enriched sources.

Keywords

Central Indian Ridge $\bullet$ Geochemistry $\bullet$ Mid-ocean ridge basalts $\bullet$ Petrology

\subsection{Introduction}

The Indian Ocean hydrothermal fields provide a unique opportunity to improve our understanding of hydrogen production in mid-ocean ridge (MOR) environments. One of these fields, the Kairei hydrothermal field (KHF), is located at the northern end of the first segment of the Central Indian Ridge (CIR-S1, as counted from the Rodriguez Triple Junction (RTJ)) and hosts the only known hydrogen-rich hydrothermal activity outside of slow-spreading ridge environments (Kumagai et al. 2008). The KHF was the first hydrothermal field discovered in the Indian Ocean (Gamo et al. 2001). Recent research by Nakamura et al. (2009) suggested that the high $\mathrm{H}_{2}$ and $\mathrm{Si}$ concentrations within hydrothermal fluids in this field were the result of serpentinization of troctolites at depth, with the derived fluids subsequently undergoing hydrothermal reactions with basaltic wall rocks beneath the KHF. In addition, olivine-rich gabbroic rocks and troctolites, including plagioclase dunites, which are representative of lithologies at deeper parts of the oceanic crust and/or at the crust-mantle boundary, have been recovered from the area around the KHF (Nakamura et al. 2009). This strongly suggests that these deep-forming rocks are exposed in the area around the KHF.

On the other hand, no evidence of ultramafic exposure is recognized in the typical mid-ocean ridge type Edmond hydrothermal field at $23^{\circ} 52^{\prime} \mathrm{S}$. Therefore, geological background between the KHF and Edmond hydrothermal field is quite different, and it is estimated that lithology and source mantle compositions along and beneath the southern CIR is heterogeneous. However, petrological and geochemical investigations with systematic sampling have not been performed along the segments of the southern CIR.

Here, we present new petrological and geochemical data for basalts exposed around the KHF with the aim of constraining the distributions of lithology and discuss the characteristics of the source mantle regions for these basalts beneath the southern segments of the CIR. A separate paper in this volume (Okino et al. Chap. 11) presents the general geology of four hydrothermal fields along the CIR and discusses the tectonic setting, with a focus on hydrothermal activity in the area.

\subsection{Geological Background and Previous Studies}

Details of the tectonic background of the southern CIR (Okino et al. Chap. 11) are summarized here. The CIR is characterized by a narrow axial valley with a slow to intermediate spreading rate $(47 \mathrm{~mm} / \mathrm{year}$ full spreading rate at $25^{\circ} \mathrm{S}$ ) relating to movement of the Somalia and Indian/ Capricorn plates. We follow the nomenclature of Briais (Briais 1995) for ridge segments and use the prefix CIR-Sx in this paper.

More than $870 \mathrm{~kg}$ of rock samples were recovered by dredging during the KH-10-6 cruise along the CIR-S1 to CIR-S4 segments of the CIR. Several dives by the submersible Shinkai 6500 were also performed during the YK05-16 cruise (Kumagai et al. 2006, 2008; Morishita et al. 2009), and the compositions of recovered basalt samples are reported in part by Kumagai et al. (Kumagai et al. 2008) and Neo (Neo

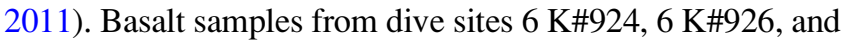
$6 \mathrm{K \# 927}$ are reported and discussed here. In addition, the characteristics of serpentinized peridotites - the dominant lithologies at sites KH-10-6DR19 and KH-10-6DR21-are discussed by Morishita et al. (Chap. 14).

The petrology and geochemistry of MORB around the RTJ that were recovered during the KH-93-3 cruise are reported and discussed by Nakamura et al. (2006). In addition, details of the petrology and geochemistry of MORB from the CIR-S1 segment, including off-ridge samples recovered during the $\mathrm{KH}-10-6$ cruise, will be discussed in future. Previous research (e.g., Price et al. 1986) has also been undertaken in this area, although no studies involving systematic sampling along the southern part of the CIR have been published to date. The locations of dredge and dive sites in this study are given in Table 13.1 and shown in Fig. 13.1, and are described in the following paragraphs.

CIR-SI: Dredge site KH-10-6DR7 is located at the northern part of the CIR-S1 segment, with sites KH-10-6DR6, -DR2，-DR4，-DR3，-DR5，-DR12，-DR11， and -DR10 located to the east of the spreading ridge at the off-ridge area of KH-10-6DR7 along the flow line of plate motion. Basaltic lithologies dominate the rocks recovered from the majority of areas, with serpentinized peridotites recovered from sites KH-10-6DR10, -DR11, and -DR12. 
Table 13.1 Locations of dredge sites during KH-10-6 cruise and submersible Shinkai 6500 dive sites during YK05-16 cruise

\begin{tabular}{|c|c|c|c|c|c|c|c|}
\hline Segment & Location & Dredge/dive sites & Latitude & Longitude & Water depth (m) & Total weight of samples (g) & Lithology \\
\hline CIR-S1 & Off ridge & KH-10-6DR1 & $-25^{\circ} 15.00^{\prime}$ & $70^{\circ} 00.2^{\prime}$ & 3,115 & 57,020 & $\mathrm{~B}, \mathrm{SP}, \mathrm{G}, \mathrm{D}$ \\
\hline CIR-S1 & Off ridge & KH-10-6DR2 & $-25^{\circ} 17.80^{\prime}$ & $70^{\circ} 01.7^{\prime}$ & 2,682 & 18,540 & $\mathrm{~B}$ \\
\hline CIR-S1 & Off ridge & KH-10-6DR3 & $-25^{\circ} 17.14^{\prime}$ & $70^{\circ} 02.0^{\prime}$ & 2,726 & 5,550 & B \\
\hline CIR-S1 & Off ridge & KH-10-6DR4 & $-25^{\circ} 17.19^{\prime}$ & $70^{\circ} 01.9^{\prime}$ & 2,778 & 2,310 & B \\
\hline CIR-S1 & Off ridge & KH-10-6DR5 & $-25^{\circ} 17.09^{\prime}$ & $10^{\circ} 02.6^{\prime}$ & 2,720 & 51,170 & B \\
\hline CIR-S1 & Off ridge & KH-10-6DR6 & $-25^{\circ} 18.53^{\prime}$ & $69^{\circ} 58.9^{\prime}$ & 3,297 & 84,440 & B \\
\hline CIR-S1 & Northern & KH-10-6DR7 & $-25^{\circ} 20.06^{\prime}$ & $69^{\circ} 56.6^{\prime}$ & 4,052 & 912 & B \\
\hline CIR-S1 & Off ridge & KH-10-6DR8 & $-25^{\circ} 13.79^{\prime}$ & $69^{\circ} 57.8^{\prime}$ & 3,886 & 3,920 & B, D \\
\hline CIR-S1 & Off ridge & KH-10-6DR9 & $-25^{\circ} 13.80^{\prime}$ & $69^{\circ} 59.5^{\prime}$ & 3,396 & 65,840 & G, SP, D, B \\
\hline CIR-S1 & Off ridge & KH-10-6DR10 & $-25^{\circ} 13.46^{\prime}$ & $70^{\circ} 04.7^{\prime}$ & 2,966 & 17,270 & $\mathrm{~B}, \mathrm{G}, \mathrm{SP}$ \\
\hline CIR-S1 & Off ridge & KH-10-6DR11 & $-25^{\circ} 14.49^{\prime}$ & $70^{\circ} 03.7^{\prime}$ & 2,725 & 22,510 & SP \\
\hline CIR-S1 & Off ridge & KH-10-6DR12 & $-25^{\circ} 15.69^{\prime}$ & $70^{\circ} 03.9^{\prime}$ & 2,551 & 96,825 & $\mathrm{~B}, \mathrm{SP}$ \\
\hline CIR-S1 & Off ridge & KH-10-6DR20 & $-25^{\circ} 23.48^{\prime}$ & $69^{\circ} 44.5^{\prime}$ & 3,160 & 146,310 & SP,G \\
\hline CIR-S1 & Off ridge & KH-10-6DR21 & $-25^{\circ} 21.39^{\prime}$ & $69^{\circ} 50.1^{\prime}$ & 3,275 & 14,890 & B,G,SP \\
\hline CIR-S1 & Off ridge & KH-10-6DR22 & $-25^{\circ} 13.40^{\prime}$ & $70^{\circ} 12.4^{\prime}$ & 3,163 & 145 & SP,B \\
\hline CIR-S2 & Northern & KH-10-6DR17 & $-24^{\circ} 37.86^{\prime}$ & $69^{\circ} 48.7^{\prime}$ & 2,882 & 8,265 & $\mathrm{D}, \mathrm{B}$ \\
\hline CIR-S2 & Northern & KH-10-6DR18 & $-24^{\circ} 45.32^{\prime}$ & $69^{\circ} 52.8^{\prime}$ & 3,821 & 1,560 & SP,G \\
\hline CIR-S2 & Southern & KH-10-6DR19 & $-25^{\circ} 06.08^{\prime}$ & $70^{\circ} 04.3^{\prime}$ & 3,054 & 204,810 & $\mathrm{SP}, \mathrm{G}$ \\
\hline CIR-S2 & Center & $6 \mathrm{~K} \# 926$ & $-24^{\circ} 52.50^{\prime}$ & $69^{\circ} 57.91^{\prime}$ & 3,545 & & B \\
\hline Knorr $^{\mathrm{b}}$ & Summit & KH-10-6DR15 & $-24^{\circ} 28.95^{\prime}$ & $69^{\circ} 55.1^{\prime}$ & 2,242 & 67,55 & B \\
\hline Knorr $^{b}$ & Summit & KH-10-6DR16 & $-24^{\circ} 31.77^{\prime}$ & $69^{\circ} 55.5^{\prime}$ & 2,268 & 10,850 & B \\
\hline Knorr $^{\mathrm{b}}$ & Western flank & $6 \mathrm{K \# 924}$ & $-24^{\circ} 28.88^{\prime}$ & $69^{\circ} 49.29^{\prime}$ & 2,783 & & B \\
\hline CIR-S3 & Northern end & KH-10-6DR14 & $-23^{\circ} 49.64^{\prime}$ & $69^{\circ} 30.0$ & 3,462 & 24,400 & B \\
\hline CIR-S3 & Northern & $6 \mathrm{~K} \# 923$ & $-23^{\circ} 52.93^{\prime}$ & $69^{\circ} 35.57^{\prime}$ & 3,547 & & B \\
\hline CIR-S3 & Center & $6 \mathrm{K \# 927}$ & $-24^{\circ} 08.06^{\prime}$ & $69^{\circ} 39.02^{\prime}$ & 3,592 & & $\mathrm{~B}$ \\
\hline CIR-S4 & Southern end & KH-10-6DR13 & $-23^{\circ} 39.92^{\prime}$ & $69^{\circ} 28.8^{\prime}$ & 3,684 & 28,925 & B \\
\hline
\end{tabular}

${ }^{\mathrm{a}}$ Abbreviations for lithology are as follows; $B$ basalt, $S P$ serpentinized peritotite, $G$ gabbro, $D$ dorelite

${ }^{\mathrm{b}}$ Knorr seamount

Locations for on bottom are shown for both dredge and dive sites

Sites KH-10-6DR20 and -DR21 are located to the west of the CIR-S1 spreading axis at the off-ridge area, and site $\mathrm{KH}$ 10-6DR21 is known to contain exposed mantle rocks (Hellebrand et al. 2002). Sites KH-10-6DR1, -DR8, and DR9 are located at to the east of the spreading axis at the offridge part of the northern segment. Basalts and dolerites were recovered from site KH-10-6DR8, and basalts, serpentinized peridotites, and gabbros recovered from sites KH-10-6DR1 and -DR9.

CIR-S2: Site KH-10-6DR19 yielded $>150 \mathrm{~kg}$ of serpentinized peridotites and is located at the southern end of the CIR-S2 segment, herein referred to as the Phoenix Knoll. The dive site 6 K\#926 by the submersible Shinkai 6500 is within the western part of the axial valley of the central section of the segment. In addition, two dredges were performed during cruise 93 by the R/V Atlantis II (Legs 5-5 and 6-10) along the southern part of the CIR-S2 segment (Price et al. 1986), with sites KH-10-6DR17 and DR18 located within the northern part of the CIR-S2 segment.
Knorr Seamount: The southern end of the CIR-S3 segment hosts a large volcano known as the Knorr Seamount; this volcano is nearly $40 \mathrm{~km}$ long by $18 \mathrm{~km}$ wide and has a rifted summit that reaches $1,700 \mathrm{~m}$ above the rift valley floor. Sites KH-10-6DR15 and -DR16 are located near the summit of the seamount, and dive site $6 \mathrm{K \# 924}$ by the Shinkai 6500 , is located on the western flank of the seamount. In addition, a single dredge was performed during the CIRCE cruise by the R/V Argo (Engel and Fisher 1969) at the northern flank of the seamount.

CIR-S3: Dive site 6 K\#927 by the Shinkai 6500 is located at the center of segment CIR-S3, and the trace element compositions of basalts from this site have previously been reported (Kumagai et al. 2008). In addition, dive site $6 \mathrm{~K} \# 923$ by the Shinkai 6500 is located within the northern part of the rift valley of segment CIR-S3, close to the Edmond hydrothermal field, and site KH-10-6DR14 is located at the northern end of segment CIR-S3.

CIR-S4: Site KH-10-6DR13 is located at the southern end of the CIR-S4 segment. 


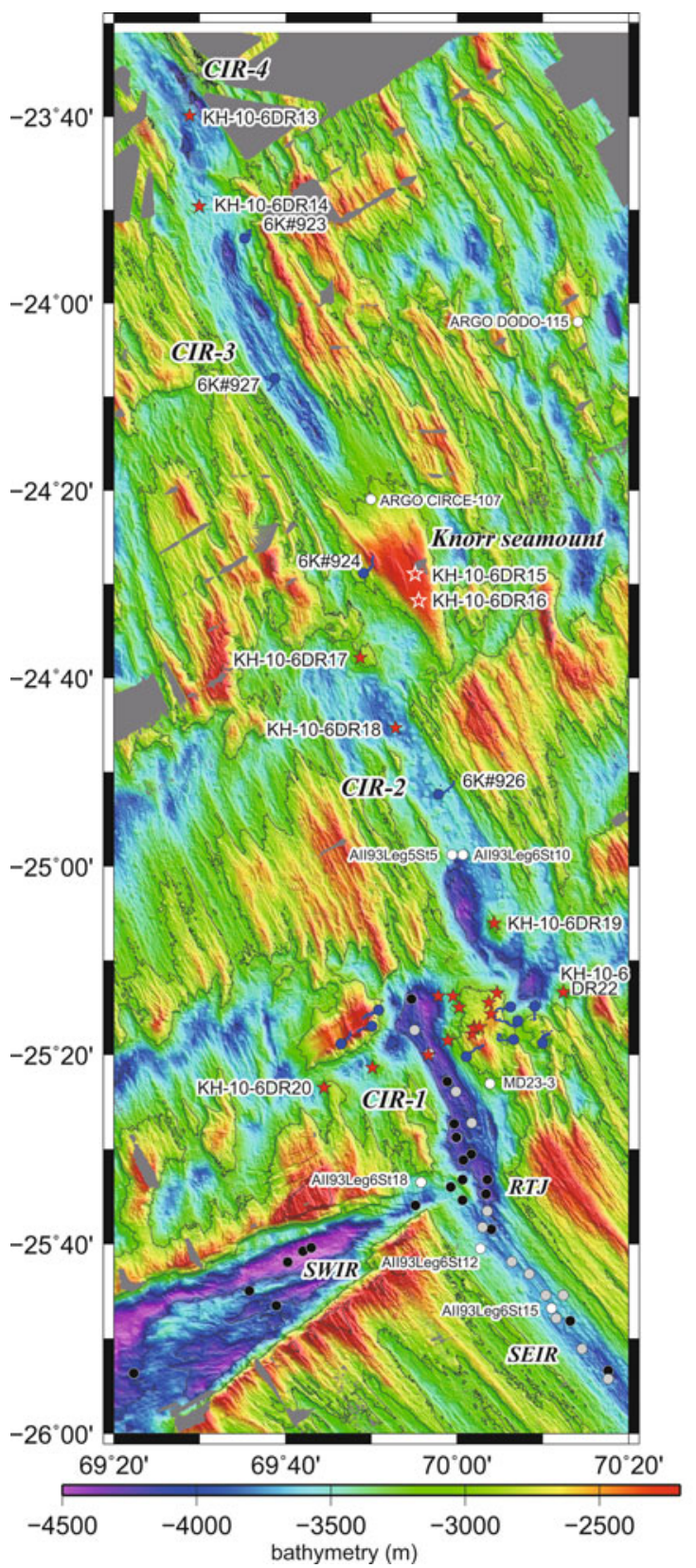

Fig. 13.1 Sampling locations with dredge and rock core samples, and submersible dive sites located on a bathymetric map (Okino et al. Chap. 11). The locations of dredge and rock core sampling undertaken during the KH-93-3 cruise are from Tamaki and Fujimoto (Tamaki and

\subsection{Petrology and Geochemistry of MORB Along the Southern CIR}

Basalts from the southern CIR (CIR-S1 to CIR-S4) are generally plagioclase-olivine phyric to sparsely phyric basalts with glass and/or glassy groundmasses, whereas off-ridge basalts within the CIR-S1 contain significant amounts of olivine phenocrysts with lesser amounts of plagioclase. The major and trace element

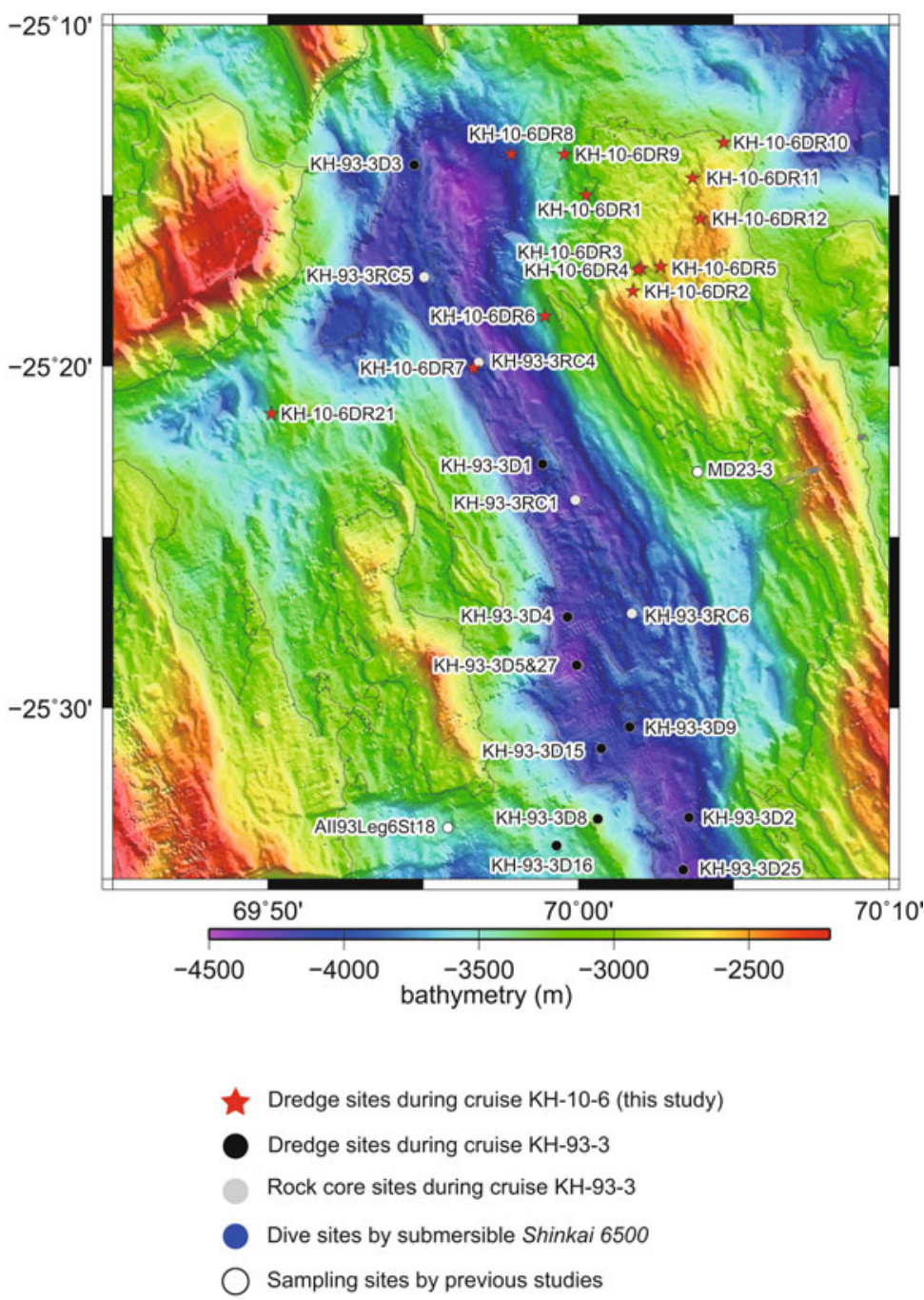

Fujimoto 1995), and the locations sampled by previous studies (Gale et al. 2013; Price et al. 1986) are sourced from the PetDB database (accessed 2013/07/04)

compositions of these samples were determined by X-ray fluorescence (XRF) and inductively coupled plasma-mass spectrometry (ICP-MS).

\subsubsection{Analytical Techniques}

The major element compositions of bulk samples were determined using XRF (Rigaku Supermini) housed at Senshu University, Japan. Prior to analysis, samples were 
dried at $950{ }^{\circ} \mathrm{C}$ before being melted at $1,200{ }^{\circ} \mathrm{C}$ in a mixture consisting of $0.9000 \mathrm{~g}$ powdered sample and $4.5000 \mathrm{~g}$ lithium tetraborate $\left(\mathrm{Li}_{2} \mathrm{~B}_{4} \mathrm{O}_{7}\right)$ flux. XRF calibration lines were determined using the approach of Sato (Sato 2010).

Trace element concentrations within basaltic glass samples were determined using laser ablation-inductively coupled plasma-mass spectrometry (LA-ICP-MS; Agilent 7500S) coupled with a $193 \mathrm{~nm}$ ArF excimer MicroLas GeoLas Q-plus laser at Kanazawa University, Japan (Morishita et al. 2005). Each analysis was performed using a $60 \mu \mathrm{m}$ spot size, a frequency of $5 \mathrm{~Hz}$, and an energy density of $8 \mathrm{~J} / \mathrm{cm}^{2}$ per pulse. A BCR2G (USGS microanalytical reference material) standard was used as the primary calibration standard, with known concentrations obtained from the GeoReM database (Jochum and Nohl 2008). Data reduction was performed using ${ }^{42} \mathrm{Ca}$ as an internal standard, employing $\mathrm{CaO}$ contents determined by electron microprobe (EPMA) and the approaches described by Longerich et al. (Longerich et al. 1996).

Trace element concentrations in crystalline MORB samples were analyzed by ICP-MS (Agilent Technologies Agilent 7500ce) at the Japan Agency for Marine-Earth Science and Technology (JAMSTEC). Prior to analysis, powdered samples were digested with a $\mathrm{HClO}_{4} / \mathrm{HF}$ mixture before undergoing an alkali fusion as outlined in Senda et al. (2014). After reaching dryness, samples were dissolved in $2 \% \mathrm{HNO}_{3}$ with a trace amount of HF. In and $\mathrm{Bi}$ were added to aliquots of samples as internal standards (Senda et al. 2014). Oxide and hydroxide interferences were subtracted from $\mathrm{Eu}$ and $\mathrm{Gd}$ peaks after analysis.

The results of the major and trace element analyses undertaken during this study are given in Suppl. 13.1 and Suppl. 13.2, respectively.

\subsubsection{Major Element Chemistry}

The $\mathrm{Mg \#}(=\mathrm{Mg} /(\mathrm{Mg}+\mathrm{Fe}))$ values of basalts analyzed during this study range from relatively primitive $(\mathrm{Mg \#}>65)$ to relatively evolved $(\mathrm{Mg} \#<50)$ compositions (Fig. 13.2). The basalts from the off-ridge of CIR-S1 segment have highly primitive compositions $(\mathrm{Mg \#}>70)$. Concentrations of $\mathrm{TiO}_{2}, \mathrm{Na}_{2} \mathrm{O}$, and $\mathrm{K}_{2} \mathrm{O}$ negatively correlate with $\mathrm{Mg} \#$ values, whereas $\mathrm{Al}_{2} \mathrm{O}_{3}$ concentrations positively correlate with $\mathrm{Mg} \#$ values. Although variations in each segment could result from the difference of modal compositions of phenocryst in each sample, these trends may represent liquid lines of descent (LLD). Several compositional trends are recognized on $\mathrm{Mg} \#$ vs. $\mathrm{TiO}_{2}, \mathrm{Na}_{2} \mathrm{O}$, and $\mathrm{K}_{2} \mathrm{O}$ diagrams, suggesting that these trends may relate to primary magmas with distinct chemical compositions.

The majority of samples from each dredge have specific major element compositions, indicating that each dredge sampled an individual flow or related flows. The only exceptions are samples from site CIR-S1 and the Knorr Seamount, where dredging appears to have sampled several flows that are exposed at these locations. Some basalt from the Knorr seamount exhibits significant $\mathrm{K}_{2} \mathrm{O}$ enrichment. Because they are enriched only in $\mathrm{K}$ in terms of trace element chemistry (see below), the enrichment might result from alteration.

$\mathrm{Na} 8$ values, calculated as the $\mathrm{Na}_{2} \mathrm{O}$ content at an $\mathrm{MgO}$ value of $8.0 \mathrm{wt} \%$, are indicative of the degree of partial melting (Klein and Langmuir 1987), where higher Na8 values are indicative of lower average degrees of partial melting, and vice versa. The $\mathrm{Na} 8$ values of the majority of basalts from the southern CIR range from 2.5 to 3.0, barring samples from the central CIR-S2 segment and the northern parts of CIR-S3 and CIR-S4, all of which are associated with basalts with $\mathrm{Na} 8$ values of $<2.5$ (Fig. 13.3).

\subsubsection{Trace Element Chemistry}

Chondrite-normalized rare earth element (REE) and primitive-mantle-normalized trace element variation diagrams for the samples analyzed during this study are shown in Fig. 13.4. Basalts from CIR-S1, -S2, and -S3 have relatively flat REE patterns that are slightly depleted in the light REE (LREE), and have trace element patterns that are slightly depleted in the highly incompatible elements, yielding patterns similar to N-MORB. Crystalline samples (KH-10-6DR18-001 and -DR18-002) obtained from the northern part of segment CIR-S2 have lower highly incompatible element concentrations than N-MORB. Basalts from the central CIR-S3 segment (samples 6 K\#927R01, -02, and -04) contain high concentrations of the REE and have minor negative Eu anomalies, suggesting that these basalts are more evolved than other samples analyzed during this study, and have undergone plagioclase fractionation.

Basalts from the CIR-S4 and the off-ridge sections of CIR-S1 are highly depleted in the LREE and highly incompatible trace elements compared with N-MORB (Workman and Hart 2005). In comparison, basalts from the Knorr Seamount have flat patterns or are slightly enriched in both the LREE and the highly incompatible elements.

Trace element ratio values (e.g., $\mathrm{La} / \mathrm{Sm}, \mathrm{Zr} / \mathrm{Y}$, and $\mathrm{Zr} / \mathrm{Nb}$ ) are dependent on the degree of partial melting of the mantle and/or the composition of the mantle, and remain relatively constant during fractionation providing that the melts evolved from the same parental magma. Basalts from the CIR have distinct trace element ratios, as exemplified by changes in $\mathrm{Zr} / \mathrm{Y}$ ratios for basalts from the study area. Basalts from the CIR-S1 segment have $\mathrm{Zr} / \mathrm{Y}$ ratios of 


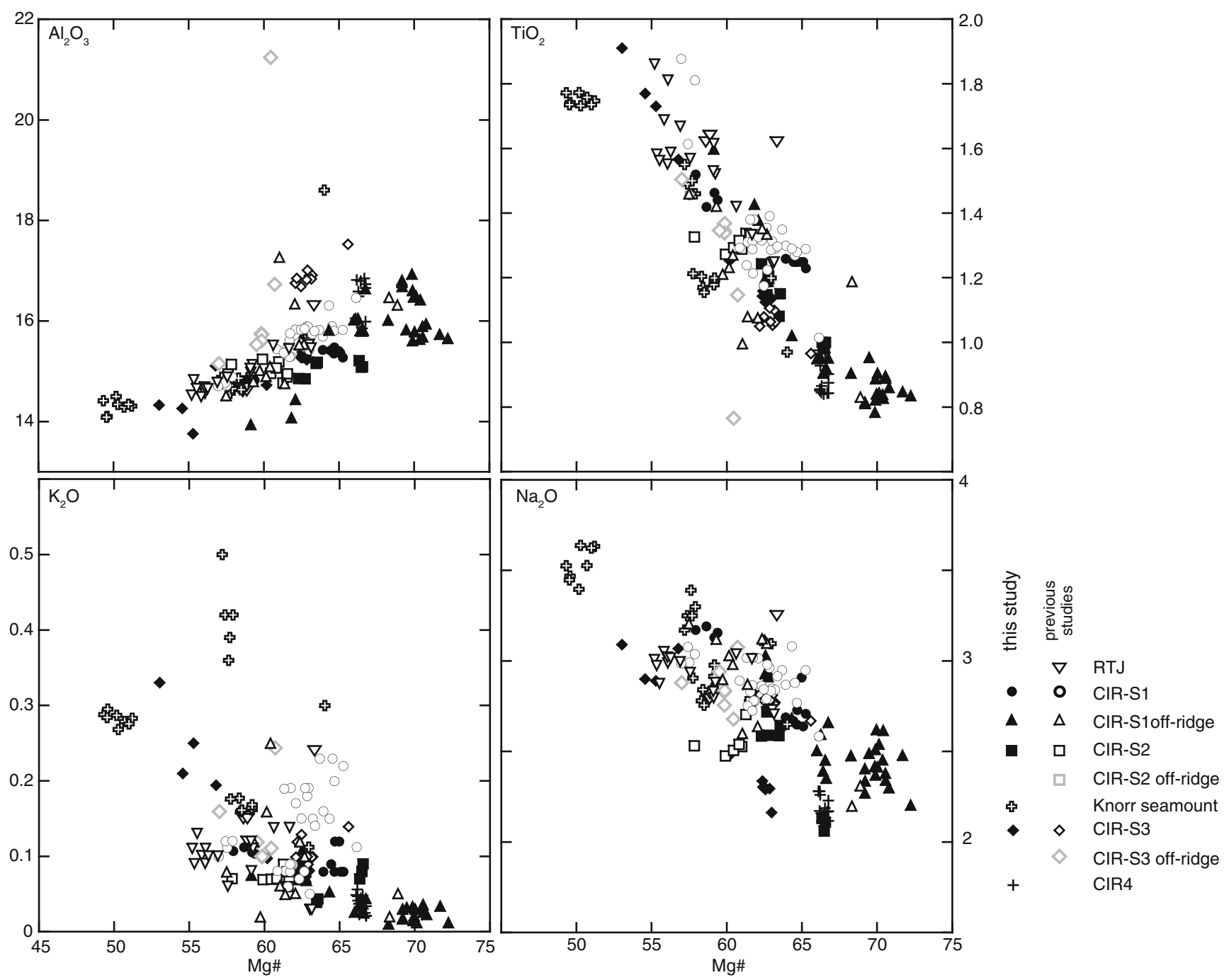

Fig. 13.2 Major element variations in $\mathrm{Mg} \#$ vs. $\mathrm{TiO}_{2}, \mathrm{Na}_{2} \mathrm{O}$, and $\mathrm{K}_{2} \mathrm{O}$ diagrams. The data for previous studies are from Nakamura et al. (2006) for the KH-93-3 cruise and from the PetDB database (accessed 2013/07/04) for all other data, including Hedge et al. (1979), Michard et al. (1986), Price et al. (1986), Engel and Fisher (1975), Engel et al. (1965), Subbarao et al. (1975), Jenner and O’Neill (2012), and Gale et al. (2013)

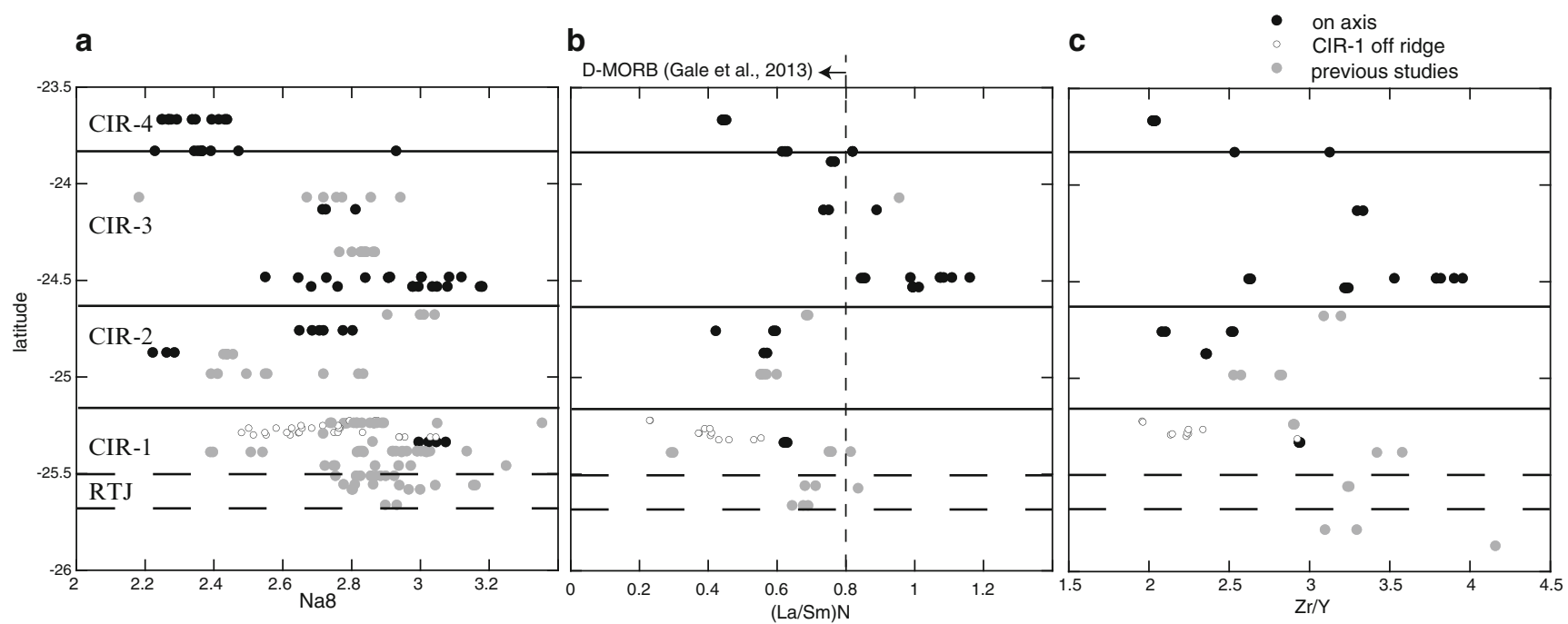

Fig. 13.3 Along-axis variations in chemical compositions of basalts from the southern CIR segments. (a) Variations in $\mathrm{Na} 8\left(\mathrm{Na}_{2} \mathrm{O}\right.$ contents at $\mathrm{MgO}=8 \mathrm{wt} \%$; Klein and Langmuir 1987), indicative of the degree of partial melting if the source mantle is homogeneous; lower $\mathrm{Na} 8$ values corresponds to higher degrees of partial melting, and vice versa. $\mathrm{Na} 8$ values in this study are calculated based on the equation by Castillo et al. (2000). (b) Variations in the La/Sm ratio normalized to N-MORB (Sun and McDonough 1989). (c) Variations in the $\mathrm{Zr} / \mathrm{Y}$ ratio. Data from previous studies were sourced from Nakamura et al. (2006) for samples from the KH-93-3 cruise and the PetDB database (accessed 2013/07/04) 


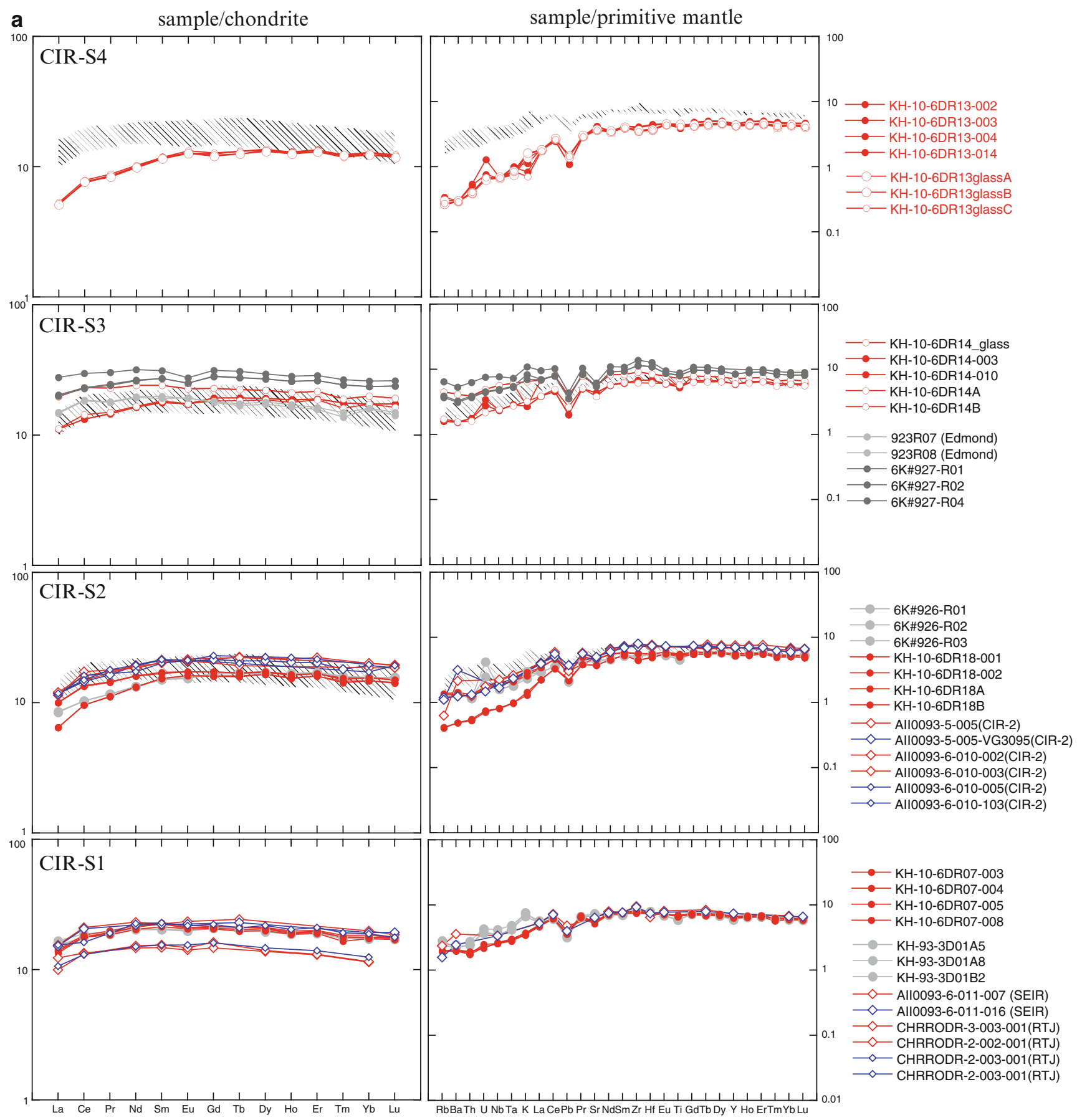

Fig. 13.4 Chondrite-normalized REE and primitive-mantlenormalized trace element variation diagrams (normalized to chondrite and primitive mantle values of Sun and McDonough (1989)). (a) MORB from the present-day spreading axis within segments CIR-S1 to CIR-S4. (b) Off-ridge MORB from CIR-S1 and the Knorr Seamount,

3.0-3.5, whereas basalts from CIR-S2 have values of 2.0-2.5 (Fig. 13.3), and basalts from CIR-S4 have values around 2.0. In addition, chondrite-normalized $\mathrm{La} / \mathrm{Sm}$ ratios $\left((\mathrm{La} / \mathrm{Sm})_{\mathrm{N}}\right)$ for these basalts range from 0.4 to 0.8 except for higher $(>1.0)$ ratios for basalts from the Knorr Seamount. a seamount at the southern end of the CIR-S3; the hatched area indicates the compositional range of MORB from CIR-S1. Data from previous studies were sourced from Nakamura et al. (2006) for samples from the KH-93-3 cruise and the PetDB database (accessed 2013/07/ 04)

The majority of basalts with $(\mathrm{La} / \mathrm{Sm})_{\mathrm{N}}$ ratios of $<0.8$ are considered to be D-MORB-type basalts according to the recently proposed classification of Gale et al. (2013), suggesting that depleted MORB end-members are widespread throughout the southern part of the CIR. 
b

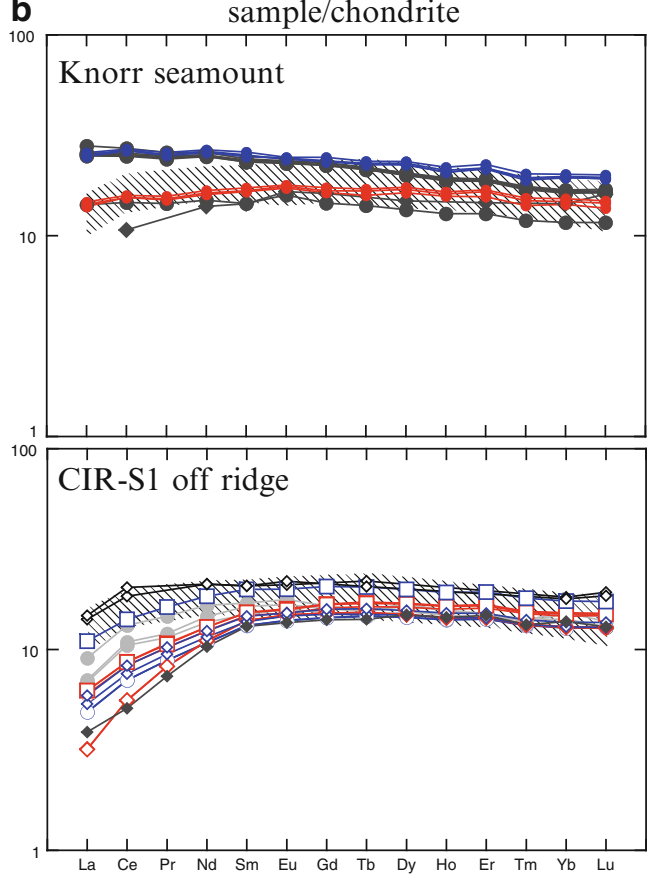

Fig. 13.4 (continued) sample/primitive mantle

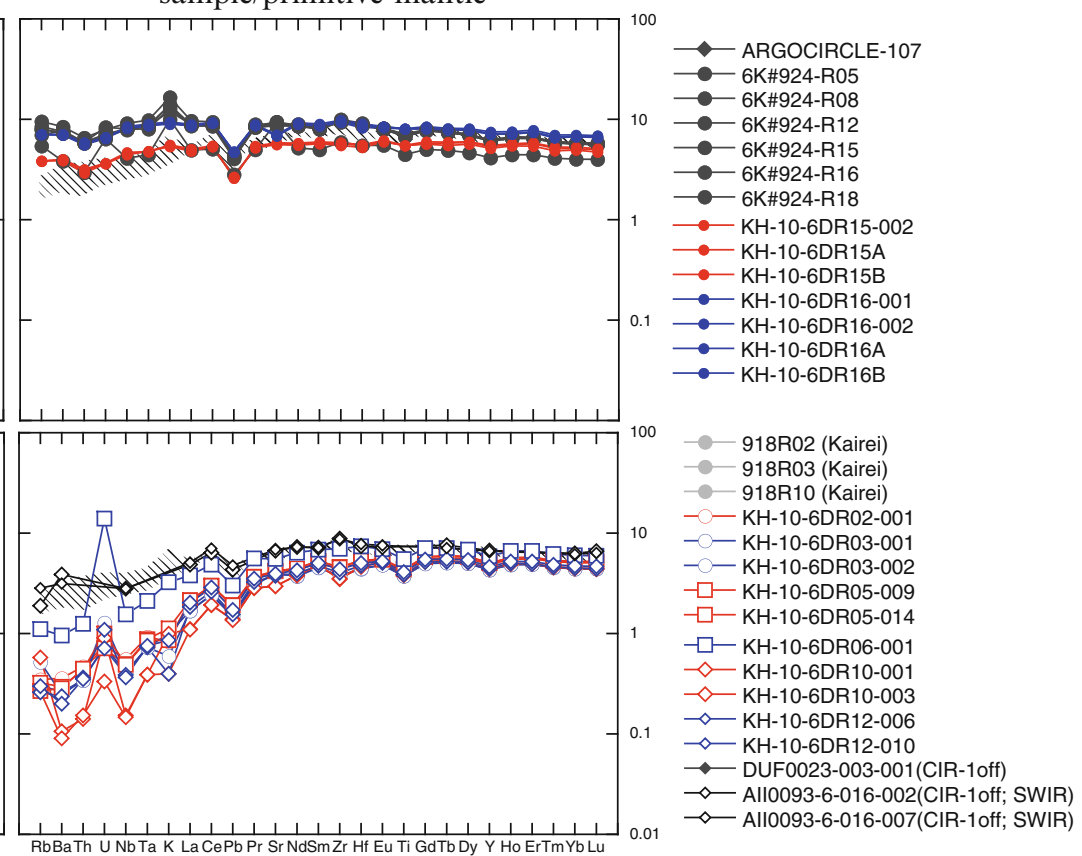

\subsection{Implications for the Source Mantle Beneath the Southern CIR}

\subsubsection{Petrogenetic Conditions}

The chemical compositions of primary basaltic magmas beneath the CIR were back-calculated from basalt compositions using the olivine maximum fractionation model (e.g., Sato 2004, and references therein). This model calculates the chemical composition of olivine in equilibrium with the basalt using Fe-Mg and Ni-Mg partitioning between olivine and silicate melts. The calculated olivine composition was then added to the original whole-rock composition at a 1:99 weight ratio, with this calculation repeated until the equilibrium olivine had a $\mathrm{NiO}$ composition equivalent to that of mantle olivine. The olivine composition that was calculated in each step was fractionated from an original primary magma to yield the basalt compositions analyzed during this study. The whole-rock composition generated by the same number of calculation steps as the olivine composition in equilibrium with the mantle represents the melt composition that was also equilibrated with mantle olivine (i.e., primary magma); the calculations and assumptions involved in this analysis are as presented by Sato (2004).

This calculation assumes that only olivine was fractionated from magma prior to eruption. If plagioclase was fractionated from these magmas, then this calculation would overestimate the $\mathrm{MgO}$ concentration of the primary magma, whereas clinopyroxene fractionation would lead to an underestimation of the $\mathrm{MgO}$ concentration of the primary magma. This indicates that the starting composition chosen for this modeling should have only crystallized olivine. Therefore, the $\mathrm{MgO}$ concentration of the estimated primary magma would be overestimated for basalts containing olivine and plagioclase phenocrysts, The results of these calculations are listed in Table 13.2.

The compositions of basalts from CIR-S1 (including off-ridge samples), CIR-S2, and CIR-S4 are equilibrated with mantle olivine without any significant fractionation. In comparison, the volcanic rocks from CIR-S3 and the Knorr Seamount equilibrated with mantle olivine after several steps of fractionation, suggesting that the MORB compositions at CIR-S1, CIR-S2, and CIR-S4 may represent the compositions of primary melts beneath these segments.

Estimated primary magma compositions are plotted in Fig. 13.5 on an olivine (Ol)-plagioclase (Pl)-quartz (Qz: silica) diagram (Walker et al. 1979) overlain with the isobaric liquid compositional trend of lherzolite determined by Hirose and Kushiro (Hirose and Kushiro 1993). The locations of these primary magmas in the figure represent the pressure (i.e., depth) where melt was fully equilibrated with mantle material or where melt was produced, indicating that off-ridge basalts from CIR-S1 are fully equilibrated with 
Table 13.2 Calculated compositions of primary melts and equilibrated olivine

\begin{tabular}{|c|c|c|c|c|c|c|}
\hline Segment & CIR-S1 & CIR-S1 off & CIR-S2 & Knorr smt & CIR-S3 & CIR-S4 \\
\hline Cruise & KH-93-3 & KH-10-6 & YK05-16 & KH-10-6 & YK05-16 & KH-10-6 \\
\hline$\underline{\text { Site }}$ & D1 & DR12 & $6 \mathrm{~K} \# 926$ & DR15 & $6 \mathrm{~K} \# 927$ & DR13 \\
\hline Sample ID & B2 & 006 & R03 & 003 & R01 & 003 \\
\hline Step & 1 & 1 & 1 & 4 & 7 & 1 \\
\hline \multicolumn{7}{|c|}{ Equilibrated melt compositions } \\
\hline$\underline{\mathrm{SiO}_{2}}$ & 51.16 & 49.78 & 50.83 & 51.37 & 51.29 & 50.36 \\
\hline $\mathrm{TiO}_{2}$ & 1.29 & 0.84 & 1.01 & 1.13 & 1.66 & 0.84 \\
\hline $\mathrm{Al}_{2} \mathrm{O}_{3}$ & 15.82 & 15.58 & 15.29 & 14.22 & 13.23 & 16.57 \\
\hline $\mathrm{FeO}^{\mathrm{a}}$ & 8.02 & 7.91 & 8.29 & 9.35 & 10.38 & 7.93 \\
\hline $\mathrm{MnO}$ & 0.14 & 0.14 & 0.14 & 0.17 & 0.16 & 0.15 \\
\hline $\mathrm{MgO}$ & 8.96 & 12.11 & 9.78 & 9.13 & 10.17 & 9.46 \\
\hline $\mathrm{CaO}$ & 11.32 & 11.36 & 12.35 & 11.69 & 9.94 & 12.49 \\
\hline $\mathrm{Na}_{2} \mathrm{O}$ & 2.95 & 2.19 & 2.14 & 2.68 & 2.78 & 2.11 \\
\hline $\mathrm{K}_{2} \mathrm{O}$ & 0.22 & 0.01 & 0.09 & 0.16 & 0.24 & 0.03 \\
\hline $\mathrm{P}_{2} \mathrm{O}_{5}$ & 0.12 & 0.08 & 0.07 & 0.12 & 0.14 & 0.07 \\
\hline $\mathrm{Ni}(\mathrm{ppm})$ & 148 & 321 & 158 & 90 & 260 & 167 \\
\hline \multicolumn{7}{|c|}{ Equilibrated olivine compositions } \\
\hline $\mathrm{Mg} \#^{\mathrm{b}}$ & 91.3 & 93.5 & 91.7 & 90.2 & 90.2 & 91.8 \\
\hline $\mathrm{NiO}(\mathrm{wt} \%)$ & 0.295 & 0.487 & 0.291 & 0.173 & 0.448 & 0.318 \\
\hline
\end{tabular}

${ }^{\text {a }}$ Total $\mathrm{Fe}$ as $\mathrm{FeO}$

${ }^{\mathrm{b}} \mathrm{Mg} \#=100 \mathrm{Mg} /(\mathrm{Mg}+\mathrm{Fe})$

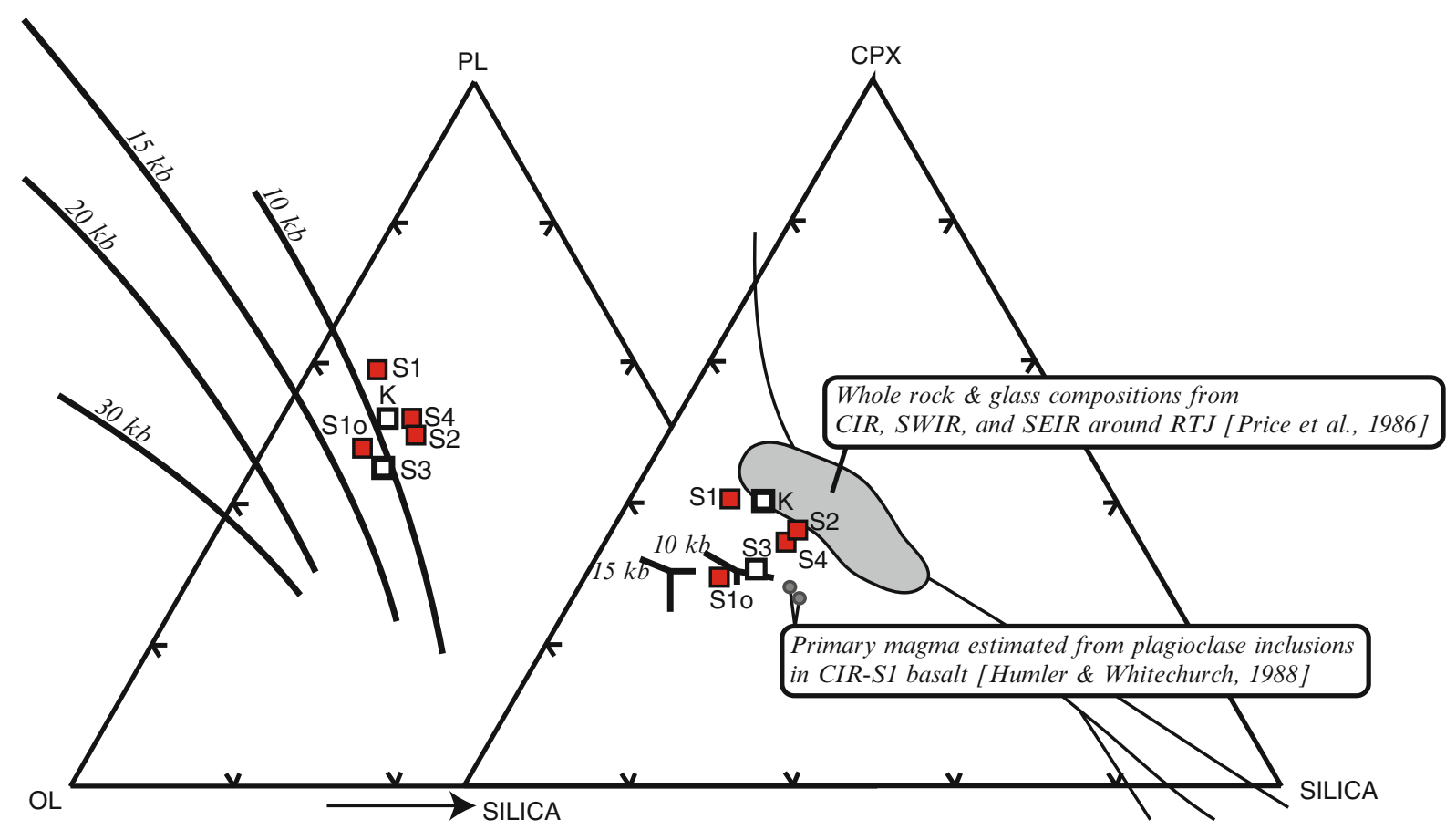

Fig. 13.5 Diagrams showing Ol (olivine)-Pl (plagioclase)-Silica $\left(\mathrm{SiO}_{2}\right)$ and $\mathrm{Ol}$ (olivine)-CPX (clinopyroxene)-Silica $\left(\mathrm{SiO}_{2}\right)$ projections of Walker et al. (1979), indicating the assumed primary magma for MORB from the southern CIR and isobaric liquid compositional trends for dry peridotites (KLB-1 and HK66) determined by Hirose and
Kushiro (1993). Also shown are MORB compositions collected near the RTJ by Price et al. (1986) and primary magma compositions for MORB from the CIR-S1 segment (Humler and Whitechurch 1988). S1: CIR-S1, S1o: CIR-S1 off-ridge, S2: CIR-S2, K: Knorr seamount, S3: CIR-S3, S4: CIR-S4 
the mantle at slightly greater depths ( $>10 \mathrm{kbar}$, equivalent to a depth of $30 \mathrm{~km}$ ), whereas basalts from other segments are fully equilibrated with the mantle at pressures of $<10 \mathrm{kbar}$. As discussed above, due to possibility of the overestimation of $\mathrm{MgO}$ concentration, the estimated pressure might exhibit upper limit value.

\subsubsection{Mantle Source Compositions}

Differences in the normalized REE and trace element patterns and trace element ratios of basalts can be explained by either differences in the composition of the source mantle for the basalts or by differences in the degree of partial melting of mantle with a similar composition in all cases. The similarities between the REE and trace element compositions of basalts from CIR-S1 to CIR-S3 indicate that these basalts were most likely all derived from a N-MORB-type mantle source, and any variations in $\mathrm{Na} 8$, $(\mathrm{La} / \mathrm{Sm})_{\mathrm{N}}$, and $\mathrm{Zr} / \mathrm{Y}$ values for these basalts probably relate to differences in the degree of partial melting. In comparison, basalts from the CIR-S4 segment are more depleted than those from CIR-S1 to -S3. One explanation of this finding is that these depletions are related to higher degrees of partial melting beneath the CIR-S4. Because basalts from the CIR-S4 have similar $\mathrm{Na} 8,(\mathrm{La} / \mathrm{Sm})_{\mathrm{N}}$, and $\mathrm{Zr} / \mathrm{Y}$ values to basalts from the CIR-S2 segment, the explanation that these basalts formed at similar degrees of partial melting is dismissed. Rather, the more depleted compositions present in CIR-S4 indicate that these basalts were sourced from a mantle region that was slightly more depleted than the mantle beneath areas CIR-S1 to CIR-S3.

Basalts from the off-ridge section of CIR-S1 have more depleted compositions than basalts from the present-day spreading axis. Basalts from near the present-day axis have similar compositions to those at the present-day spreading axis, whereas basalts distal from the spreading axis are more depleted. This suggests that the source mantle beneath the CIR-S1 area was more depleted during formation of the offridge basalts in this area compared with the source mantle for more recent (and present-day) basalts.

Although basalts from the Knorr Seamount are significantly enriched when compared with those from the presentday spreading axis, the REE compositions of these seamount basalts provide no lines of evidence of a hotspot influence. Interaction between the Reunion hotspot and CIR segments to the south of $20^{\circ} \mathrm{S}$ has been proposed by Murton et al. (2005). However, plotting these data on the geochemical discrimination between plume-related and N-MORB/continental magmas of Fitton et al. (1997) indicates that basalts from the

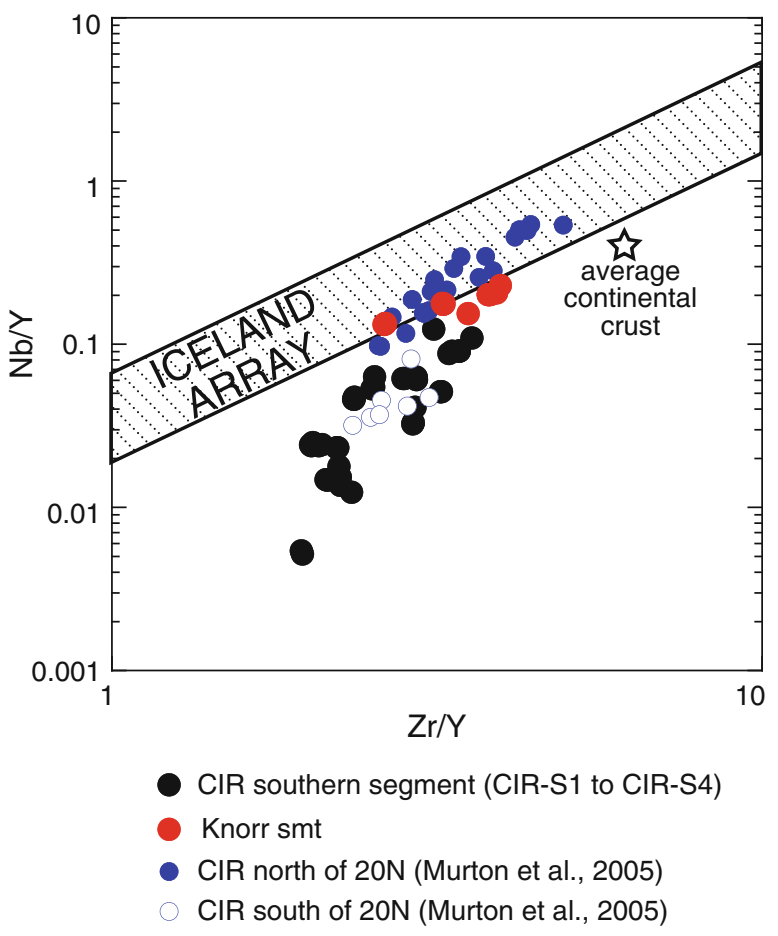

Fig. 13.6 Diagram showing $\mathrm{Nb} / \mathrm{Y}$ and $\mathrm{Zr} / \mathrm{Y}$ variations in plumeaffected Iceland basalts (Iceland array of Fitton et al. (1997)); N-MORB that is free of plume- or hotspot-influence plots beneath the Iceland array. MORB from the CIR to the north of $20^{\circ} \mathrm{S}$ (Murton et al. 2005) plots within the array and is therefore considered to have interacted with plume-related material (Murton et al. 2005), whereas MORB from the CIR to the south of $20^{\circ} \mathrm{S}$ (Murton et al. 2005) and from the southern part of the CIR, including from the Knorr Seamount (this study), plot beneath the array, indicating that these basalts are free of any plume or hotspot influence

southern CIR, including basalts to the south of $20^{\circ} \mathrm{S}$ as reported by Murton et al. (2005), do not show any plume or hotspot influence (Fig. 13.6). Kumagai et al. (2007) reported He isotope ratios $\left({ }^{3} \mathrm{He} /{ }^{4} \mathrm{He}\right)$ of basaltic glasses sampled during the YK05-16 cruise by the Shinkai 6500, and these basalts have $R_{A}$ values well within global MORB variations ( $7.9 R_{A}$ vs. $8 \pm 1 \mathrm{R}_{\mathrm{A}}$ for global MORB). In comparison, the majority of basalts around the RTJ, including a segment within the southeast Indian Ridge, have slightly higher He isotope ratios ( 8.4 $\mathrm{R}_{\mathrm{A}}$; Kumagai and Kaneoka 2005; Nishio et al. 1998). This indicates that basalts from the Knorr Seamount are not hotspot-related. Furthermore, Hirahara et al. (2007) reported $\mathrm{Sr}-\mathrm{Nd}$ isotope compositions of basalts from the Knorr Seamount that were sampled during the YK05-16 cruise by the Shinkai 6500; these data indicated that the basalts of the Knorr Seamount were probably sourced from a region containing a mix of depleted MORB mantle (DMM) and recycled ancient oceanic crustal material. 


\subsubsection{Distribution of Depleted and Enriched Mantle}

Calculated pressures (i.e., depth) at which melts were fully equilibrated with mantle material or where melts were produced do not change significantly between basalts from segments of the southern CIR (from CIR-S1 to CIR-S4, including the off-ridge area of CIR-S1 and the Knorr Seamount). However, these basalts have distinct trace element compositions, suggesting that the mantle beneath the southern CIR is laterally heterogeneous, with compositional variations present within mantle material at a given depth.

Price et al. (1986) used isotope systematics to determine that depleted components within Indian Ocean MORB are not isotopically homogeneous due to the effects of contamination with different amounts of an ancient (Dupal) component. Recent research into trace element variations in MORB samples from near the RTJ suggests that these variations can be explained by variable contamination of a depleted MORB source mantle by small amounts (up to $\sim 1 \%$ ) of lower continental crust-derived melt (Nakamura et al. 2006).

This two-component model, consisting of a large volume of depleted source mantle and a small volume of ancient enriched component, indicates that MORB compositional variations along the southern CIR (from CIR-S1 to CIRS4) may relate to changes in the degree of mixing between these components. The source mantle beneath the segments between CIR-S1 and CIR-S3 may be compositionally homogeneous, with this mantle representing the proposed mix of voluminous depleted and minor enriched components. In comparison, the off-ridge depleted MORB within the CIR-S1 segment may have been sourced from only the depleted portion of this heterogeneous mantle, whereas basalts from the Knorr Seamount may have been sourced from a region of the mantle that contained an increased amount of the enriched component.

\subsubsection{Implications for Tectonic Development of the Southern CIR}

An oceanic core complex (OCC), known as $25^{\circ} \mathrm{S}$ OCC, is exposed along a detachment fault to the west of the northern CIR-S1 (Morishita et al. 2009), with another OCC containing troctolites, olivine gabbros, and dunites reported to the east of the KHF (Kumagai et al. 2008). These OCCs are considered to represent massifs associated with nontransform offsets (NTOs). Observations during recent submersible dives, sample recovery by dredging, and geophysical investigations (Okino et al. Chap. 11) have identified another NTO massif that contains mantle peridotites. The location of this NTO along the segment boundary between CIR-S1 and CIR-S2 suggests that this area has undergone a significant temporal and spatial variation in melt supply, with small amounts of melt supplied during the formation of these NTO massifs.

The formation of the $25^{\circ} \mathrm{S}$ OCC was initiated at the southern inside corner of CIR-S2 during the Matuyama reversal polarity chron (Sato et al. 2009). A geophysical reconstruction indicates that the majority of the NTO massif, including the $25^{\circ} \mathrm{S} \mathrm{OCC}$, formed after either the BrunhesMatuyama boundary or the Jaramillo event (Okino et al. Chap. 11). Therefore, the mantle between CIR-S1 and CIR-S2 may have changed to a more depleted composition, producing the off-ridge basalts in the CIR-S1 area, with present-day mantle beneath the spreading axis being more enriched, producing N-MORB-type basalts at that time.

It is known that the volcanism occur at off-ridge area, and recently large lava fields erupted two to several hundred kilometers off the fast-spreading East Pacific Rise are recognized (Geshi et al. 2007; Umino et al. 2008). The formation age of basaltic rocks from the off-ridge area of the CIR-S1 segment is not clear because no analyses of age determination were performed. The magnetization distribution along the CIR-S1 segment is mostly symmetry (Okino et al. Chap. 11). Therefore, it is plausible that basaltic rocks from the off-ridge area of the CIR-S1 segment might be formed at the ancient spreading center unlike the East Pacific Rise.

\subsection{Summary}

We investigated the petrology and geochemistry of MORB in segments CIR-S1 to CIR-S4 within the southern part of the CIR, with the aim of constraining the lithological distributions. Our findings are summarized as follows.

(1) MORB from segments CIR-S1 to CIR-S3 have NMORB-type compositions, and calculated primary melt compositions indicate that the basaltic melts from which these MORB formed, equilibrated with mantle olivine at a pressure of $10 \mathrm{kbar}$. Particularly, MORB from the CIRS1, CIR-S2, and CIR-S4 segments derived directly from the primary melts with only minor fractionation.

(2) The trace element compositions of MORB from segments CIR-S1 to CIR-S3 are typical of N-MORB compositions, whereas basalts from the CIR-S4 segment are slightly depleted, indicative of the depletion of the source mantle beneath this segment. Off-ridge basalts from segment CIR-S1 are more depleted than any other MORB within the southern CIR.

(3) MORB from the Knorr Seamount is enriched but has not significantly interacted with hotspot-derived materials, as supported by previous isotope analysis $(\mathrm{He}, \mathrm{Sr}, \mathrm{Nd})$. It is likely that the enriched magmas within this seamount relate to differences in the abundance of enriched 
components within the mantle source for these magmas, rather than the introduction of any plume-related components.

(4) The presence of depleted MORB within the off-ridge section of the CIR-S1 segment indicates that the ancient (i.e., at least as old as the Matuyama reversal polarity chron) source mantle along the boundary between the CIR-S1 and CIR-S2 segments was highly depleted.

\begin{abstract}
Acknowledgements We thank the captain, crew, and scientific party on board the R/V Hakuho-maru during cruise KH-10-6. This research was supported by the following grants and programs: the Ministry of Education, Culture, Sports, Science and technology (MEXT), Grant-inAid for Scientific Research on Innovative Areas "Project TAIGA: Trans-crustal Advection and In-situ biogeochemical process of Global sub-seafloor Aquifer" (20109002) and a FY2010 Research Fellowship of Senshu University for H.S. H.S. also thanks Ms. K. Komiyama for preparation of thin sections and XRF samples. Maps were drawn using GMT software.
\end{abstract}

Open Access This chapter is distributed under the terms of the Creative Commons Attribution Noncommercial License, which permits any noncommercial use, distribution, and reproduction in any medium, provided the original author(s) and source are credited.

\section{References}

Briais A (1995) Structural-analysis of the segmentation of the CentralIndian-Ridge between $20^{\circ} 30^{\prime} \mathrm{s}$ and $25^{\circ} 30^{\prime} \mathrm{s}$ (Rodriguez-Triple-Junction). Mar Geophys Res 17(5):431-467. doi:10.1007/BF01371787

Castillo PR, Klein E, Bender J, Langmuir C, Shirey S, Batiza R, White $\mathrm{W}$ (2000) Petrology and $\mathrm{Sr}, \mathrm{Nd}$, and $\mathrm{Pb}$ isotope geochemistry of mid-ocean ridge basalt glasses from the $11^{\circ} 45^{\prime} \mathrm{N}$ to $15^{\circ} 00^{\prime} \mathrm{N}$ segment of the East Pacific Rise. Geochem Geophys Geosyst 1:1011. doi:10.1029/1999GC000024

Engel CG, Fisher RL (1969) Lherzolite, anorthosite, gabbro, and basalt dredged from the mid-Indian ocean ridge. Science 166:1136-1141

Engel CG, Fisher RL (1975) Granitic to ultramafic rock complexes of the Indian Ocean ridge system, western Indian Ocean. Geol Soc Am Bull 86:1553

Engel CG, Fischer RL, Engel AE (1965) Igneous rocks of the Indian Ocean Floor. Science 150:605-610

Fitton JG, Saunders AD, Norry MJ, Hardarson BS, Tayler RN (1997) Thermal and chemical structure of the Iceland plume. Earth Planet Sci Lett 153:197-208

Gale A, Dalton CA, Langmuir CH, Su Y, Schilling J-G (2013) The mean composition of ocean ridge basalts. Geochem Geophys Geosyst 14:489-518. doi:10.1029/2012GC004334

Gamo T, Chiba H, Yamanaka T (2001) Chemical characteristics of newly discovered black smoker fluids and associated hydrothermal plumes at the Rodriguez Triple Junction, Central Indian Ridge. Earth Planet Sci Lett 193:371-329

Geshi N, Umino S, Kumagai H, Sinton JM, White SM, Kishimoto K, Hilde TW (2007) Discrete plumbing systems and heterogeneous magma sources of a $24 \mathrm{~km}^{3}$ off-axis lava field on the western flank of East Pacific Rise $14^{\circ} \mathrm{S}$. Earth Planet Sci Lett 258:61-72

Hedge C, Futa K, Engel C, Fisher R (1979) Rare Earth abundances and $\mathrm{Rb}-\mathrm{Sr}$ systematics of basalts, gabbro, anorthosite and minor granitic rocks from the Indian Ocean Ridge System, Western Indian Ocean. Contrib Mineral Petrol 376:373-376
Hellebrand E, Snow JE, Hoppe P, Hofmann AW (2002) Garnet-field melting and late-stage refertilization in "Residual " abyssal peridotites from the Central Indian Ridge. J Petrol 43 (12):2305-2338

Hirahara Y, Nakamura K, Sato H, Hanyu T, Kumagai H, Suzuki K, Senda R (2007) Origin of the Knoll seamount, the Rodrigues Triple Junction. InterRidge Japan meeting abstract

Hirose K, Kushiro I (1993) Partial melting of dry peridotites at high pressures: determination of compositions of melts segregated from peridotite using aggregates of diamond. Earth Planet Sci Lett $114: 477-489$

Humler E, Whitechurch H (1988) Petrology of basalts from the Central Indian Ridge (lat. $25^{\circ} 23^{\prime} \mathrm{S}$, long. $70^{\circ} 04^{\prime} \mathrm{E}$ ): estimates of frequencies and fractional volumes of magma injections in a two-layered reservoir. Earth Planet Sci Lett 88:169-181

Jenner FE, O'Neill HStC (2012) Analysis of 60 elements in 616 ocean floor basaltic glasses. Geochem Geophys Geosyst 13, Q02005. doi:10.1029/2011GC004009

Jochum KP, Nohl U (2008) Reference materials in geochemistry and environmental research and the GeoReM database. Chem Geol 253:50-53

Klein EM, Langmuir CH (1987) Global correlations of ocean ridge basalt chemistry with axial depth and crustal thickness. J Geophys Res 92:8089-8115

Kumagai H, Kaneoka I (2005) Noble gas signatures around the Rodriguez Triple Junction in the Indian Ocean - Constraints on magma genesis in a ridge system. Geochim Cosmochim Acta 69:5567-5583

Kumagai H, Okino K, Joshima M, Morishita T, Sawaguchi T, Nakamura K, Neo N, Shibuya T, Sato T, Takaesu M, Okada S (2006) Preliminary Cruise Report YK05-16 Leg.1 Yokosuka/ Shinkai6500 "URANIWA" Expedition. JAMSTEC

Kumagai H, Joshima M, Morishita T, Nakamura K, Sato H, Arai S, YK05-16Leg1 Shipboard and Shore-Based Scientific Party (2007) An anomalous seamount filling the axial valley of CIR, Indian Ocean: unstable spreading at intermediate-rate spreading ridge. JpGU meeting, J169-012

Kumagai H, Nakamura K, Toki T, Morishita T, Okino K, Ishibashi J-I, Tsunogai U, Kawagucci S, Gamo T, Sshibuya T, Sawaguchi T, Neo N, Joshima M, Sato T, Takai K (2008) Geological background of the Kairei and Edmond hydrothermal fields along the Central Indian Ridge: implications of their vent fluids' distinct chemistry. Geofluids 8:239-251. doi:10.1111/j.1468-8123.2008.00223.x

Longerich HP, Jackson SE, Gunther D (1996) Laser ablation inductively coupled plasma mass spectrometric transient signal data acquisition and analyte concentration calculation. J Anal At Spectrom 11:899-904

Michard A, Montigny R, Schlich R (1986) Geochemistry of the mantle beneath the Rodriguez Triple Junction and the South-East Indian Ridge. Earth Planet Sci Lett 78:104-114

Morishita T, Ishida Y, Arai S (2005) Simultaneous determination of multiple trace element compositions in thin $(<30 \mu \mathrm{m})$ layers of BCR-2G by $193 \mathrm{~nm}$ ArF excimer laser ablation-ICP-MS: implications for matrix effect and element fractionation on quantitative analysis. Geochem J 39:327-340

Morishita T, Hara K, Nakamura K, Sawaguchi T, Tamura A, Arai S, Okino K, Takai K, Kumagai H (2009) Igneous, alteration and exhumation processes recorded in abyssal peridotites and related fault rocks from an oceanic core complex along the Central Indian Ridge. J Petrol 50(7):1299-1325. doi:10.1093/petrology/egp025

Murton BJ, Tindle AG, Milton JA, Sauter D (2005) Heterogeneity in southern Central Indian Ridge MORB: implications for ridge - hot spot interaction. Geochem Geophys Geosyst 6:Q03E20. doi:10. 1029/2004GC000798

Nakamura K, Sato H, Sato Y, Ishii T (2006) Petrological and geochemical study of the Indian Ocean MORB from the Rodriguez Triple 
Junction, Indian Ocean. EOS Trans AGU 87(52) Fall Meet Suppl, Abstract B31B-1104

Nakamura K, Morishita T, Bach W, Klein F, Hara K, Okino K, Takai K, Kumagai H (2009) Serpentinized troctolites exposed near the Kairei Hydrothermal Field, Central Indian Ridge: insights into the origin of the Kairei hydrothermal fluid supporting a unique microbial ecosystem. Earth Planet Sci Lett 280:128-136

Neo N (2011) Petrology of the basalts of the Central Indian Ridge and regional variations of MORBs along the eastern part of the Southwest Indian Ridge. Dissertation thesis for Doctoral program in Fundamental Sciences, Graduate School of Science and Technology, Niigata University, $99 \mathrm{pp}$

Nishio Y, Ishii T, Gamo T, Sano Y (1998) Volatile element isotopic systematics of the Rodrigues Triple Junction Indian Ocean MORB: implications for mantle heterogeneity. Earth Planet Sci Lett 170:241-253

Price RC, Kennedy AK, Riggs-Sneeringer M (1986) and F.A. Frey (1986) Geochemistry of basalts from the Indian Ocean triple junction: implications for the generation and evolution of Indian Ocean ridge basalts. Earth Planet Sci Lett 78:379-396

Sato H (2004) Mineral compositions of MORB from the Australian Antarctic Discordance (AAD): implications for mantle source characteristics. In: Pedersen RB, Christie DM, Miller DJ (eds) Proceedings of the ODP, science results, 187 [Online]. http:// www-odp.tamu.edu/publications/187_SR/202/202.htm

Sato H (2010) Quantitative analyses with X-ray fluorescence analyzer of major elements for rock samples. Bulletin of the Institute of Natural Sciences, Senshu University, No. 41, pp 15-23 (in Japanese)
Sato T, Okino K, Kumagai H (2009) Magnetic structure of an oceanic core complex at the southernmost Central Indian Ridge: analysis of shipboard and deep-sea three-component magnetometer data. Geochem Geophys Geosyst 10(6). doi:10.1029/ 2008GC002267

Senda R, Chang Q, Kimura J-I (2014) Evaluation of a rapid, effective sample digestion method for trace element analysis of granitoid samples containing acid-resistant minerals: Alkali fusion after acid digestion. Geochemi J 48:99-103. doi:10.2343/geochemj.2.0280

Subbarao KV, Hekinian R, Chandrasekharam D (1975) Large ion lithophile elements and $\mathrm{Sr}$ and $\mathrm{Pb}$ isotopic variation in volcanic rocks from the Indian ocean. Ind Ocean Geol Biostratigr Stud Following Deep Sea Drill Legs 9:259-278

Sun S-S, McDonough WF (1989) Chemical and isotopic systematics of oceanic basalts: implications for mantle composition and processes. In: Saunders AD, Norry MJ (eds) Magmatism in the Ocean Basins, vol 42. Geological Society of London, Specical Publication, London, pp 313-345

Tamaki K, Fujimoto H (1995) Rodriguez triple junction expedition in the Indian Ocean: Ocean Research Institute, the University of Tokyo, Tokyo, 183 pp

Umino S, Geshi N, Kumagai H, Kishimoto K (2008) Do off-ridge volcanoes on the East Pacific Rise originate from the Moho transition zone? J Geogr 117:190-219

Walker D, Shibata T, Delong SE (1979) Abyssal tholeiites from the Oceanographer Fracture Zone, II Phase equilibria and mixing. Contrib Mineral Petrol 70:111-125

Workman RK, Hart SR (2005) Major and trace element composition of the depleted MORB mantle (DMM). Earth Planet Sci Lett 231:53-72 